\title{
Effects of Different Postharvest Storage Methods on the Quality Parameters of Chestnuts (Castanea sativa Mill.)
}

\author{
Engin Ertan', Esra Erdal, Gülsüm Alkan, and Burak E. Algül \\ Department of Horticulture, Agriculture Faculty, Adnan Menderes \\ University, Aydin, Turkey
}

Additional index words. chestnut, harvest, storage, quality, biochemical

\begin{abstract}
This trial was initiated in the harvest season of 2010 to determine the effects of traditional and cold storage on the fruit quality properties of chestnuts during the harvest and postharvest periods. Physical and biochemical analyses were conducted on fruit samples collected about once every 2 weeks from the middle of September until the end of December. Specifically, the shell and kernel colors (hue, chroma), water activity (aw), and total sugar (\%), total starch (\%), total carbohydrate (\%), and tannin (ppm) contents were determined. Under traditional and cold storage conditions, the total sugar content of the chestnuts increased whereas the total starch content decreased during the storage period. In addition, the maximum tannin content was measured in fruit that was cold stored for a period of 60 days.
\end{abstract}

Chestnut (Castanea sativa Mill.) is one of the most important tree nuts in the world. According to the Food and Agriculture Organization (FAO) Statistical Database, the worldwide chestnut production is $1,998,880$ tons. Chestnut fruits are highly regarded and widely consumed throughout Europe, America, and Asia. In addition, chestnuts are one of the most popular nuts in the oriental world. Chestnuts are mainly cultivated in China (1,650,000 tons), Republic of Korea (70,000 tons), Turkey (59,789 tons), and Italy (52,000 tons) (FAO, 2014).

Chestnuts are rich in starch and sugars, primarily monosaccharides and disaccharides such as sucrose, glucose, fructose, and raffinose (Bernardez et al., 2004; De la Montana Miguelez et al., 2004). In addition, chestnuts differ from other nuts for their low fat content which makes them ideally suited for high complex carbohydrate and low fat diets (Bounous, 2009) and they have a unique flavor and taste. Due to large proportion of moisture and sugar content, enzyme activity and pericarp characteristics, the shelf life of chestnuts is very limited (Correia et al., 2009). Therefore, chestnuts are frozen, cold stored, or dried to extend their storage period. However, the nuts have a high moisture content and are therefore susceptible to insect damage and fungal decay after harvest, resulting in high perishability (Miller, 2009; Tzortzakis and Metzidakis, 2012).

\footnotetext{
Received for publication 20 Nov. 2014. Accepted for publication $20 \mathrm{Feb} .2015$.

This research was supported by The Commission of Scientific Research Project of Adnan Menderes University. The authors would like to thank The Commission of Scientific Research Project of Adnan Menderes University, for its meritorious support.

${ }^{1}$ To whom reprint requests should be addressed; e-mail eertan@adu.edu.tr.
}

The main storage problems affecting chestnuts are the presence of insect worms (Cydia splendana $\mathrm{Hb}$, Cydia fagliglandana Zel., and Curculio elephas Gyll) and the development of fungi, mainly Cyboria, which blackens the flesh, but also Rhizopus sp., Fusarium sp., Collectotrichum sp., Phomopsis sp. (Breisch, 1993; Washington et al., 1997; Wells and Payne, 1980; Xiao-qing et al., 2009), Aspergillus sp., Penicillium sp. (Marinelli et al., 2009), Alternaria sp., Trichothecium sp., Botrytis sp., Fusicoccum sp., Phoma sp. (Xiao-qing et al., 2009), Sclerotinia sp., and Gibberella sp. (Donis-Gonzalez et al., 2009a).

Chestnut quality is measured by external factors such as color, shape, size, surface blemishes, and molds, which are very important for consumer acceptance. Internal disorders may result from anatomical or physiological changes such as moisture loss, chemical conversion, discoloration, senescence, microorganism attack, cell breakdown (physiological decay), or insect injury (Upchurch et al., 1993; Wang et al., 2000). Weight losses due to dehydration and infestation by insects and microorganisms are the two main problems in chestnut preservation (Marinelli et al., 2009; Pinto et al., 2007; Talasila et al., 1995; Tian et al., 2009). Different postharvest preservation treatments have been used to preserve the nutritional and sensory properties of the fruit (Bounous, 2002; Conedera et al., 2005) and to keep the fresh commodities against physiological and biological losses during postharvest periods, such as water curing (Bassi et al., 2005; Jermini et al., 2006; Marinelli et al., 2009), low temperature, MA storage (Miller, 2009), and CA storage (Tzortzakis and Metzidakis, 2012), coatings on the surface of chestnut fruits (i.e., chitosan, carrageenan) (Tian et al., 2009), and various chemical sanitizers (i.e., hydrogen peroxide, peracetic acid, ozone) (Donis-Gonzalez et al., 2009b).
Notwithstanding, in Turkey, chestnut growers are not used any treatments to harvested chestnuts to reduce contaminants and water losses before storage.

Chestnut fruits should be considered as fresh fruit for storage purposes because they have a $40 \%$ to $45 \%$ humidity ratio under normal conditions (Karaçal1, 2004). The humidity ratio of fruits should be maintained within a certain level to ensure good storage. Cold storage (CS) is the best method to ensure appropriate storage conditions for fruit (Soylu, 2004). Chestnuts can withstand CS because they are not susceptible to damage caused by low temperatures. The best preservation conditions for chestnuts are -1 to $-2{ }^{\circ} \mathrm{C}$ (Jermini et al., 2006; Rouves and Prunet, 2002) with a relative humidity $(\mathrm{RH})$ of $90 \%$ (Mencarelli, 2004).

Harvest and postharvest losses are high due to incorrect storage methods (SM) and nut quality is threatened by pest and diseases. Many SM exist to prolong and maintain the quality of nuts but many growers lack the technique (Bounous, 2009).

Miller (2009) stated that, quality of chestnut has two major components: characteristics and condition. Condition is mainly determined by environmental factors, especially postharvest handling, and the time interval after harvest. Condition is comprised of attributes like moisture content, insect infestation, fungal decay (mold), and sugar content. The most important environmental factors are temperature and humidity. These factors directly affect the moisture and sugar content of chestnut kernels.

In Turkey, chestnut growers typically store their crops using traditional methods. For example, chestnuts are buried with their burs in a pit under trees in the orchard and are covered with plants such as fern. This is the most commonly used method, especially in the Aegean Region in the western part of Turkey. Using this method for postharvest storage, the moisture level of the chestnut fruit is maintained and the sugar content increases from the time that the fruit separates from the burs until the middle of winter (Soylu, 2004), after which the nuts are sold.

Extensive research has been conducted on the nutrient content of chestnuts, effect of storage on fruit quality properties, and protection against microbes. However, there are no studies on the effects of different SM on the quality parameters of chestnuts. Some researchers evaluated soluble sugars, starch, and polyphenols as quality parameters, of the chestnut kernel in their articles (Cristofori et al., 2009; Tian et al., 2009; Portela et al., 2009; Vasconcelos et al., 2009).

To maintain the quality and extend the shelf life of chestnuts, it is essential that they are adequately stored. This study aimed to evaluate the effects of different SM (i.e., traditional storage (TS) and CS) and length of storage $(0,15,30,45$, and $60 \mathrm{~d})$ on the quality attributes of chestnut fruits (i.e., kernel and shell color, water activity, total sugar, total starch, total carbohydrate, and tannin content). 


\section{Materials and Methods}

Chestnut samples and storage treatments. Chestnut (C. sativa Mill.) samples from the "N-23-1 genotype," which were previously selected for their high nut quality and high yield among natural populations (Ertan et al., 2007), were collected from orchards located in Kuscular village $\left(38^{\circ} 02^{\prime} 32.87^{\prime \prime} \mathrm{N}\right.$, $28^{\circ} 28^{\prime} 34.18^{\prime \prime}$ E, $1060 \mathrm{~m}$ altitude) in the Nazilli district of Aydın province in western Turkey, during the second fortnight of Oct. 2010. The orchards have loamy soil, which is saltless and slightly alkaline, with good mineral and poor organic matter content (Seferoğlu and Ertan, 2009).

Well-formed chestnuts without any physical injury on the outer skin were selected immediately after harvesting. Before the treatments, chestnuts were completely mixed and placed in pure water where the majority of decayed, empty, or insects damaged chestnuts were eliminated by their proclivity to float, as healthy chestnuts tend to sink. Then, the fruits were divided equally and subjected to two different SM, i.e., TS or CS. The CS chestnut samples were placed into $1-\mathrm{kg}$ plastic bowls, covered with stretch film and stored at $2 \pm 1{ }^{\circ} \mathrm{C}$ and $85 \% \pm 1 \% \mathrm{RH}$ (Koyuncu et al., 2003). The TS chestnut samples were stored using the TS method, i.e., the samples (with burs) were buried in the orchard under trees belonging to the same genotype. Temperature and moisture values were recorded hourly with data logger device in chestnut orchard and it was determined that average temperature was $14.76{ }^{\circ} \mathrm{C}$, and average moisture was $78.30 \%$ during trial period.

During the 2-month storage period, duplicate sampling was conducted at 15-day intervals: samples were collected on the first day of storage (25 Oct. 2010) and after 15,30, 45 , and $60 \mathrm{~d}$. Chestnuts samples were randomly collected from each storage treatment until 29 Dec. 2010, and the chestnut quality parameters were determined immediately. The experiment consisted of 10 treatments (2 $\mathrm{SM} \times 5 \mathrm{~d}$ of storage).

Physical and biochemical traits. Nuts were collected from each treatment during the postharvest period. The physical and biochemical characteristics of each fruit sample were determined at the beginning of the storage period (time 0 ) followed by 15-day intervals for a period of 2 months (Table 1).

The shell color $(\mathrm{Sc})$ and kernel color $(\mathrm{Kc})$ of 20 fruits were determined at three different positions using a colorimeter (Minolta model CR-300, Japan). The color readings were displayed as average $L^{*} a^{*} b^{*}$ values, where $\mathrm{L}^{*}$ represents the lightness/darkness dimension; positive and negative $a^{*}$ values indicate redness and greenness, respectively, and positive and negative $b^{*}$ values indicate yellowness and blueness, respectively. The results were expressed according to the CIELab color space through the $\mathrm{L}^{*}$ (luminosity), $\mathrm{h}$ (hue angle, $\mathrm{h}=\tan ^{-1} \mathrm{~b}^{*} / \mathrm{a}^{*}$ ) and $\mathrm{C}^{*}$ (saturation index or chroma, $\mathrm{C}^{*}=\left[\mathrm{a}^{* 2}+\mathrm{b}^{* 2}\right]^{1 / 2}$ ) coordinates (Cecchini et al., 2011).
The water activity (Aw) in a kernel was determined using a water activity device (TH-500, Novosina, Switzerland) at $25^{\circ} \mathrm{C}$.

To determine the biochemical characteristics, the outer shells of the chestnut fruits were removed, the fruits were dried in an oven at $65^{\circ} \mathrm{C}$ to a constant weight, and were then ground. All biochemical analyses were replicated three times.

The anthrone method was used to determine the total sugar content (TSC) and total starch content (TStC) that constituted the total carbohydrate content (TCC) (Morris, 1948) using the Shimadzu ultraviolet 160-A model spectrophotometer. The absorbance values were measured spectrophotometrically at $620 \mathrm{~nm}$ and the results are reported on a dry matter basis.

The tannin content (TC) was determined using Folin-Denis reagent according to the AOAC (1990) (Canbolat et al., 2007). Chestnut flour ( $1 \mathrm{~g})$ was placed in a volumetric flask containing $75 \mathrm{ml} \mathrm{H}_{2} \mathrm{O}$. After shaking, the mixture was left overnight. Then, $5 \mathrm{ml}$ Folin-Denis reagent and $10 \mathrm{ml}$ saturated $\mathrm{Na}_{2} \mathrm{CO}_{3}$ solution were added and diluted to volume with $\mathrm{H}_{2} \mathrm{O}$. The solution was mixed well and was filtered through glass wool after $30 \mathrm{~min}$. Absorbance values were determined spectrophotometrically at $760 \mathrm{~nm}$. The quantitative analysis was made using a calibration with tannic acid. Tannin data were expressed as mg tannic acid per $100 \mathrm{~g}$ of dry weight.

Data analysis. A random parcel experimental design was used in this study with three replications. Data were first tested for normality and then subjected to an ANOVA. Sources of variation were treatments (SM) and number of storage days (DS). An ANOVA was performed for each variable and the least significant difference (LSD) was calculated for an appropriate interaction level $(P \leq 0.05)$ using Jump.

\section{Results and Discussion}

Variance analysis was conducted to examine the effects of SM on the quality parameters of chestnuts. The F-values from the variance analysis are presented in Table 2. The Sc and Kc values are presented as an average.

The F-values of the $\mathrm{SM} \times$ days of storage (DS) interaction were significant $(P \leq 0.01)$ for water activity (Aw), TSC $(P \leq 0.01)$, and TC $(P \leq 0.05)$. However, the interaction was not significant for TStC or TCC (Table 3 ). The physical and biochemical traits related to the SM (i.e., TS or CS), DS, and storage method $\times$ days of storage $(\mathrm{SM} \times \mathrm{DS})$ interaction are shown in Table 3.

The SM $\times$ DS interaction for water activity (Aw) differed between the SM. For example, the maximum Aw was measured in the CS treatment after $60 \mathrm{~d}$ of storage compared with $30 \mathrm{~d}$ of storage under TS conditions. These values were $\approx 0.974$ and $0.971 \%$ for the CS and TS treatment, respectively. The minimum water activity (Aw) values were measured in chestnuts stored for $15 \mathrm{~d}(0.958 \%$ and $0.957 \%$
Table 1. Physical and biochemical traits of nuts used for determining of different storage methods on chestnut quality.

\begin{tabular}{cc}
\hline Trait symbol & Trait description \\
\hline Physical characteristics of nuts \\
\multicolumn{3}{c}{ Shell color } \\
Sc & (L, a, b, hue, chroma) \\
& Kernel color \\
Kc & $(\mathrm{L}, \mathrm{a}, \mathrm{b}$, hue, chroma) \\
Aw & Activity of water $(\%)$ \\
Biochemical characteristics of nuts \\
TSC & Total sugar content $(\mathrm{g} / 100 \mathrm{~g})$ \\
TStC & Total starch content $(\mathrm{g} / 100 \mathrm{~g})$ \\
& Total carbohydrates \\
TCC & content $(\mathrm{g} / 100 \mathrm{~g})$ \\
TC & Tannin content $(\mathrm{ppm})$ \\
\hline
\end{tabular}

Table 2. F-values from the analysis of variance of the physical and biochemical traits as affected by storage methods (SM) and days of storage (DS).

\begin{tabular}{lc}
\hline & Source of \\
Traits & variation SM $\times$ DS \\
\hline Aw & $9.217^{* *}$ \\
TSC & $22.958^{* *}$ \\
TStC & $0.171 \mathrm{NS}$ \\
TCC & $0.042 \mathrm{NS}$ \\
TC & $3.856^{*}$ \\
\hline
\end{tabular}

Ns, ${ }^{*}, * *$ Nonsignificant or significant at $P \leq 0.05$ or 0.01 , respectively.

See Table 1 for trait abbreviations.

in the TS and CS treatment, respectively) (Table 3).

The TSC of the chestnuts varied between $1.54 \mathrm{~g} / 100 \mathrm{~g}$ and $11.46 \mathrm{~g} / 100 \mathrm{~g}$ depending on the interaction between SM and DS. The maximum TSC was measured in chestnuts stored under TS conditions for $15 \mathrm{~d}$. The minimum TSC was measured on the initial day ( $0 \mathrm{~d}$ of storage) in both treatments. The TSC measured after $30 \mathrm{~d}$ of storage was generally higher under TS compared with CS conditions. However, the TSC tended to increase over time from 45 to $60 \mathrm{~d}$ of storage under CS compared with TS conditions. Sugar accumulation has been detected in chestnuts stored under cold conditions (particularly $<10{ }^{\circ} \mathrm{C}$ ). Kınay and Karaçalı (2001) reported that sugar accumulates in chestnuts during storage and there is a deceleration of respiration, resulting in a longer time period needed for starch and sugar accumulation. Under essentially all environmental conditions, there is some conversion of starch to sucrose, i.e., sugar content increases over time. The conversion of starch to sucrose occurs most rapidly in response to drying conditions, but temperatures near $0{ }^{\circ} \mathrm{C}$ also cause an increase in sugar (Miller, 2009). There was a significant interaction between the SM and DS in the TC, which differed significantly between SM for all time periods except the initial day ( $0 \mathrm{~d}$ of storage). The TC ranged from 856.55 to $1767.51 \mathrm{ppm}$. The TC detected in the present study is higher than previously reported values (Vasconcelos et al., 2010). Little work has been conducted on the determination of TC of chestnut fruit.

Various aromatic compounds, including simple phenolics and more complex tannins, have been detected in chestnut tissues. Phenolics 
in the pellicle of seeds can influence nut taste, giving astringency and bitterness in fresh chestnuts, if the adherence is high and removal difficult. Polyphenols could be involved in the peel ability of fruits destined to transformation and industry utilizations (Cristofori et al., 2009). The phenolic content (gallic and ellagic acid) of chestnut fruit has been previously analyzed. These acids have been linked to various positive health effects. Low levels (0.01-0.02 mg/100 g edible portion) of these compounds have been reported in chestnut fruits (Vasconcelos et al., 2010).

Maximum TC values were measured in fruit stored under CS conditions, and the highest value was obtained at the end of the postharvest storage period ( $60 \mathrm{~d}$ of storage). According to some references (Belur et al., 2010; Gaugler and Grigsby, 2009; Ilori et al., 2007; Xiang-wen and Ping, 2009; Xiaodong et al., 2013) storing the chestnuts in not refrigerated conditions, fungi and bacteria may contaminate the tannic polymers and deteriorate them. The tannins play a role protecting the tissues from pathogens and consequently reduce the risk of infections. For this reason, storing chestnuts in cold atmosphere reduces the deterioration of the tannins by microorganisms and, consequently allows a higher protection of the chestnuts. The increase in concentration of tannins, when they are cold stored, is not due to better biochemical synthesis but, on the contrary to a lower deterioration of the molecules. Besides, Vasconcelos et al. (2009) reported that, considering all the cultivars, there was a significant increase in the phenolics from fresh chestnut to stored chestnut during 3 months at $\pm 0{ }^{\circ} \mathrm{C}$ and HR $90 \%$.

The TStC and TCC were unaffected by the $\mathrm{SM} \times \mathrm{DS}$ interaction. The initial TStC and TCC ( $0 \mathrm{~d}$ of storage) were the highest, i.e., $28.54 \mathrm{~g} / 100 \mathrm{~g}$ and $30.08 \mathrm{~g} / 100 \mathrm{~g}$ under TS and CS conditions, respectively. The TCC decreased gradually during the postharvest storage period for TS and CS. However, the TStC values tended to decrease during the postharvest storage period under CS conditions. The decrease in starch during storage at low $\left(1{ }^{\circ} \mathrm{C}\right)$ temperatures was described previously (Nomura et al., 1995) and is in accordance with the present study after $60 \mathrm{~d}$ of storage under CS conditions. The decrease in starch during the storage period may be explained by the enzymatic catabolism of starch into soluble sugars (Vasconcelos et al., 2009). Besides, Tian et al. (2009) reported that, starch content of noncoated chestnuts decreased during storage. It is thought that the hydrolysis of starch and accumulation of soluble sugar are the main metabolic processes in harvested fruits ( $\mathrm{Li}$ et al., 2006). The contents of soluble sugar were affected by the speed of starch hydrolysis as well as by the respiration rate, and there was a positive relation between the amylase activity and sugar content in stored chestnut (Jiang et al., 2004).

The TStC values tended to increase during the postharvest storage period under TS conditions when the initial time was ignored. These findings agree with previous work (Jaynes, 1979; Kınay and Karaçal1, 2001).
The increase in starch during the storage period under TS conditions may be explained by the high temperatures (average $14.76{ }^{\circ} \mathrm{C}$ ) (Karaçalı, 2004).

In general, the total sugar, starch, and carbohydrate contents determined in this study do not lie within the levels reported in other studies. It is likely that the lower starch and higher sugar contents of the nuts resulted from changes in physiological processes (Tzortzakis and Metzidakis, 2012). The differences may be due to losses of carbohydrates during long storage periods of the nuts in this study (Uylaser et al., 2009) and the

variability of climatic conditions and genotypic differences in the cultivars selected. Several studies showed important correlations between chemical compositions of chestnuts and environmental conditions, with significant differences among genotypes and cultivation areas (Borges et al., 2007; De la Montana Miguelez et al., 2004).

The shell and kernel hue angle (h) and chroma $\left(\mathrm{C}^{*}\right)$ values were colorimetrically determined for each treatment and storage period (Figs. 1 and 2). The shell changed color (as indicated by a decrease in $\mathrm{h}$ and $\mathrm{C}^{*}$ values), whereas $L^{*}$ remained constant in

Table 3. The effect of storage methods, days of storage and storage methods $\times$ days of storage interaction on physical and biochemical characteristics of chestnut.

\begin{tabular}{|c|c|c|c|c|c|}
\hline \multirow[b]{2}{*}{ Treatment } & \multicolumn{5}{|c|}{ Traits } \\
\hline & Aw $(\%)$ & TSC (g/100 g) & $\mathrm{TStC}(\mathrm{g} / 100 \mathrm{~g})$ & TCC $(\mathrm{g} / 100 \mathrm{~g})$ & TC (ppm) \\
\hline \multicolumn{6}{|c|}{ Storage methods (SM) } \\
\hline $\mathrm{TS}$ & $0.965 \mathrm{a}$ & $7.43 \mathrm{a}$ & 12.42 & 19.86 & $1,044.71 \mathrm{~b}$ \\
\hline $\mathrm{CS}$ & $0.963 \mathrm{~b}$ & $5.39 \mathrm{~b}$ & 14.38 & 19.77 & $1,659.21 \mathrm{a}$ \\
\hline LSD (\%5) & $0.002 *$ & $1.04 * *$ & $10.56 \mathrm{NS}$ & $10.65 \mathrm{NS}$ & $167.71 * *$ \\
\hline \multicolumn{6}{|c|}{ Days of storage (DS) } \\
\hline $0 \mathrm{~d}$ & $0.964 \mathrm{bc}$ & $1.54 \mathrm{c}$ & 28.54 & 30.08 & $1,669.08 \mathrm{a}$ \\
\hline $15 \mathrm{~d}$ & $0.957 \mathrm{~d}$ & $7.31 \mathrm{~b}$ & 10.72 & 18.03 & $1,281.26 \mathrm{~b}$ \\
\hline $30 \mathrm{~d}$ & $0.966 \mathrm{~b}$ & $6.97 \mathrm{~b}$ & 10.61 & 17.58 & $1,246.67 \mathrm{~b}$ \\
\hline $45 \mathrm{~d}$ & $0.963 \mathrm{c}$ & $8.98 \mathrm{a}$ & 7.26 & 16.25 & $1,239.84 \mathrm{~b}$ \\
\hline $60 \mathrm{~d}$ & $0.971 \mathrm{a}$ & $7.25 \mathrm{~b}$ & 9.85 & 17.11 & $1,322.95 \mathrm{~b}$ \\
\hline LSD $(\% 5)$ & $0.003 * *$ & $1.65 * *$ & $16.71 \mathrm{NS}$ & $16.84 \mathrm{NS}$ & $265.17 *$ \\
\hline \multicolumn{6}{|c|}{$\mathrm{SM} \times \mathrm{DS}$ interactions $\mathrm{z}^{\mathrm{z}}$} \\
\hline $\mathrm{TS} \times 0 \mathrm{~d}$ & $0.964 \mathrm{a}$ & $1.54 \mathrm{a}$ & 28.54 & 30.08 & $1,669.08 \mathrm{a}$ \\
\hline $\mathrm{CS} \times 0 \mathrm{~d}$ & $0.964 \mathrm{a}$ & $1.54 \mathrm{a}$ & 28.54 & 30.08 & $1,669.08 \mathrm{a}$ \\
\hline $\mathrm{TS} \times 15 \mathrm{~d}$ & $0.958 \mathrm{a}$ & $11.46 \mathrm{a}$ & 6.87 & 18.33 & $949.72 \mathrm{~b}$ \\
\hline $\mathrm{CS} \times 15 \mathrm{~d}$ & $0.957 \mathrm{a}$ & $3.16 \mathrm{~b}$ & 14.58 & 17.74 & $1,612.81 \mathrm{a}$ \\
\hline $\mathrm{TS} \times 30 \mathrm{~d}$ & $0.971 \mathrm{a}$ & $10.44 \mathrm{a}$ & 7.59 & 18.03 & $869.82 \mathrm{~b}$ \\
\hline $\mathrm{CS} \times 30 \mathrm{~d}$ & $0.962 \mathrm{~b}$ & $3.50 \mathrm{~b}$ & 13.63 & 17.14 & $1,623.51 \mathrm{a}$ \\
\hline $\mathrm{TS} \times 45 \mathrm{~d}$ & $0.965 \mathrm{a}$ & $8.70 \mathrm{a}$ & 8.87 & 17.57 & $856.55 \mathrm{~b}$ \\
\hline $\mathrm{CS} \times 45 \mathrm{~d}$ & $0.961 \mathrm{~b}$ & $9.27 \mathrm{a}$ & 5.65 & 14.93 & $1,623.13 \mathrm{a}$ \\
\hline $\mathrm{TS} \times 60 \mathrm{~d}$ & $0.969 \mathrm{~b}$ & $5.05 \mathrm{~b}$ & 10.22 & 15.27 & $878.39 \mathrm{~b}$ \\
\hline $\mathrm{CS} \times 60 \mathrm{~d}$ & $0.974 \mathrm{a}$ & $9.46 \mathrm{a}$ & 9.49 & 18.96 & $1,767.51 \mathrm{a}$ \\
\hline LSD $(\% 5)$ & $0.004 * *$ & $2.34 * *$ & $23.63 \mathrm{NS}$ & $23.82 \mathrm{NS}$ & $375.01 *$ \\
\hline
\end{tabular}

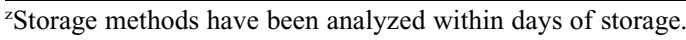

Ns, *,**Nonsignificant or significant at $P \leq 0.05$ or 0.01 , respectively.

See Table 1 for trait abbreviations.

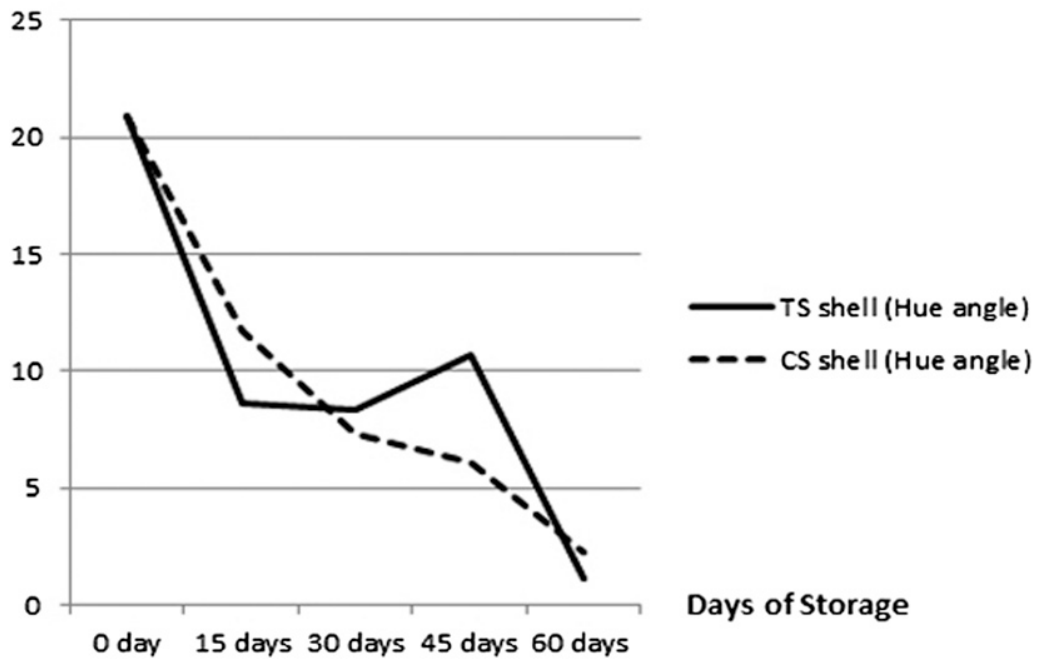

Fig. 1. Trend of the hue angle from beginning to end of storage for TS and CS methods for chestnut shell. 


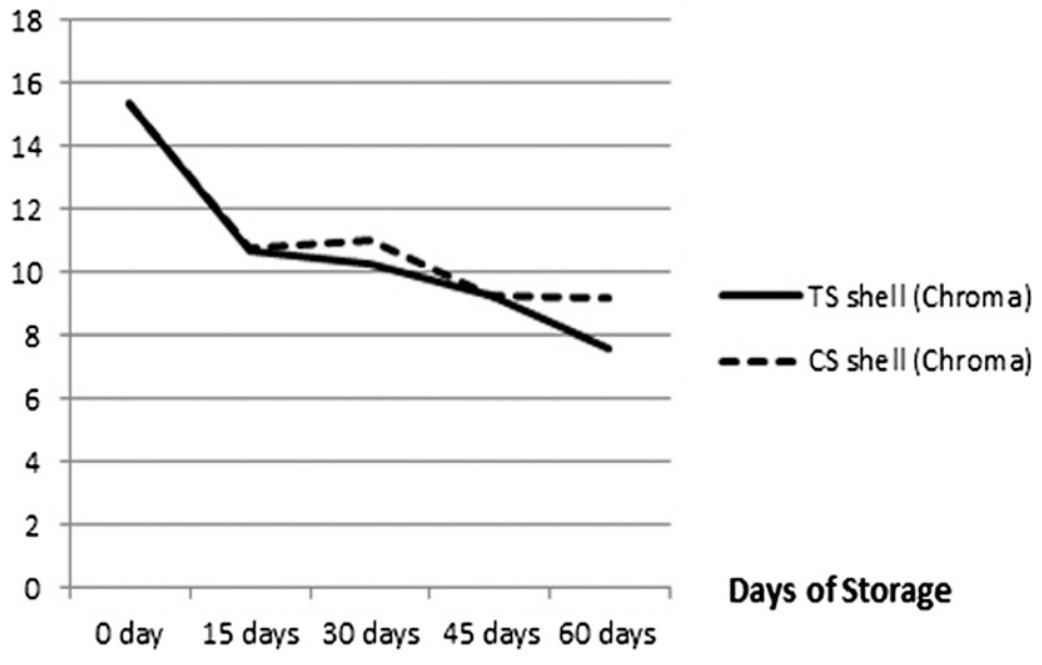

Fig. 2. Trend of the chroma from beginning to end of storage for TS and CS methods for chestnut shell.

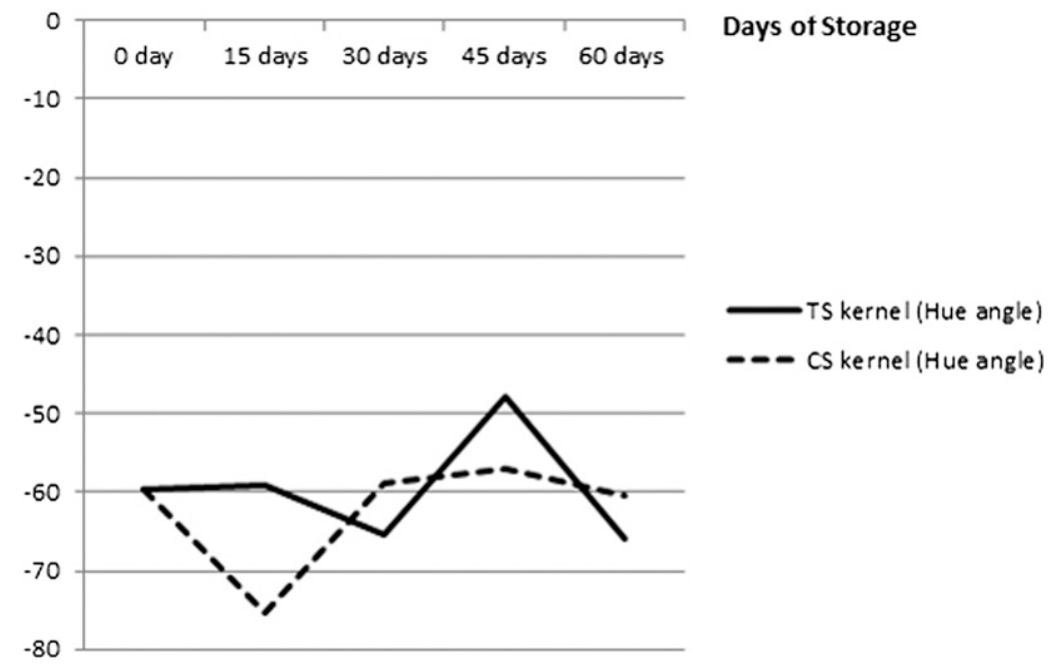

Fig. 3. Trend of the hue angle from beginning to end of storage for TS and CS methods for chestnut kernel.

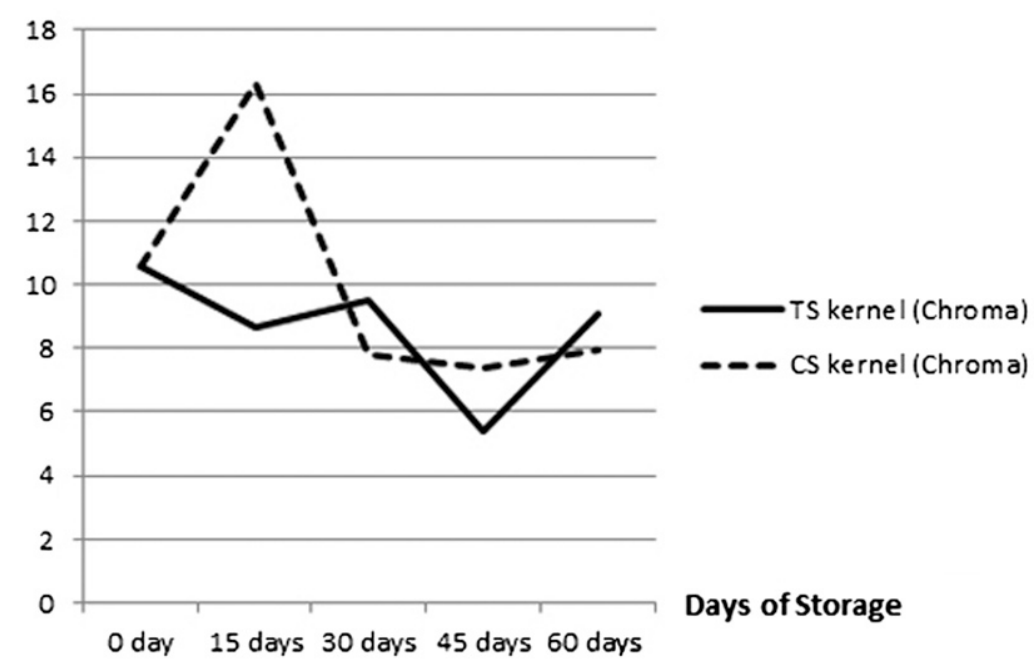

Fig. 4. Trend of the chroma from beginning to end of storage for TS and CS methods for chestnut kernel.

both treatments. The $\mathrm{h}$ and $\mathrm{C}^{*}$ values decreased with an increase in the storage period. The color changes in the chestnut kernels in relation to SM and DS are shown in Figure 4A and $\mathrm{B}$, respectively. The chestnut shell and kernel gradually darkened in color in both treatments but this change was relatively slower under CS conditions (Figs. 1-4). The kernel was green initially and gradually changed to yellow. This color change was slight under CS conditions but more rapid and unstable under TS conditions. The chroma values indicated that the kernel color dulled with an increase in the storage time (Figs. 3 and 4).

\section{Conclusions}

In this study, higher quality chestnuts were obtained under CS conditions. In addition, TS can negatively affect the quality of the chestnut fruit. For example, some mycotoxins may occur at high temperatures and water activity values (Barkai-Golan and Paster, 2008). DonisGonzalez et al. (2009c) stated that chestnut kernels from the Japanese $\times$ European cultivar Colossal stored fresh $\left(4{ }^{\circ} \mathrm{C}\right)$ for more than $120 \mathrm{~d}$ could accumulate mycotoxins. Under TS conditions, temperatures are high and uncontrolled, and stored fruits have higher Aw values compared with $\mathrm{CS}$ conditions. Some researchers emphasize the necessity of using water activity as a preservation parameter for nuts instead of moisture content, and water activity should be carefully controlled during storage (Bianco et al., 2001). Therefore, TS conditions are not suitable for the preservation of fruit quality. A previous study reported that fungal diseases increased when chestnuts were stored at room temperature compared with low temperature storage, and temperature acted as a major factor in disease development (NourEldin et al., 1995).

In the present study, the TSC of chestnuts increased whereas the TStC decreased during the storage period. Cristofori et al. (2009) stated that some chestnut cultivars have a minor content of starch and a higher content of sugar could be grown to improve fresh consumption. In addition, maximum tannin values were measured at the end of the postharvest storage period in fruit that was cold stored. Considering the role of phenolic compound as inhibitors, the importance of this phenomenon in the potential reduction of the fruit surface damaging microflora is emphasized (Marinelli et al., 2009).

In conclusion, $\mathrm{CS}$ conditions maintained chestnut quality, and low temperature is the main factor that affects chestnut quality.

\section{Literature Cited}

AOAC. Official Method of Analysis. 15th ed 1990. Association of Official Analytical Chemists, Washington DC.

Barkai-Golan, R. and M. Paster. 2008. Mycotoxins in fruit and vegetables. Academic Press of Elsevier, San Diego, CA.

Bassi, D., M.C. Casiraghi, I. Mignani, A. Vercesi, and G. Delaidelli. 2005. Effecto dei trattamenti postraccolta e dei metodi conservazione sulla qualita delle castagne. Atti IV Convegno Nazionale Castagno Montella (AV), 20-22 Ottobre: 244-269.

Belur, P.D., G. Mugeraya, and S. Subbalaxmi. 2010. Studies on the extracellular tannase from newly isolated Bacillus thurangiences BN2. Proceedings of the 2009 International Conference on Chemical, Biological and Environmental Engineering. p. 379-384.

Bernardez, M., J. Miguelez, J. Queijeiro, and J. Queijeiro. 2004. HPLC determination of sugars 
in varieties of chestnut fruits from Galicia (Spain). J. Food Compos. Anal. 17:63-67.

Bianco, A.M., G. Boente, M.L. Pollo, and S.L. Resnik. 2001. Influence of oil content on sorption isotherms of four varieties of peanut at $25^{\circ} \mathrm{C}$. J. Food Eng. 47:327-331.

Borges, O.P., J.S. Crvalho, P.R. Correia, and A.P. Silva. 2007. Lipid and fatty acids profiles of Castanea sativa Mill. chestnuts of 17 native Portuguese cultivars. J. Food Compos. Anal. 20:80-89.

Bounous, G. 2002. II Castagno-Coltura, ambiente e utilizzazioni in İtalia e del mondo. Ed agricole, Bologna.

Bounous, G. 2009. Chestnut industry development and quality of the productions. Acta Hort. 844:21-26.

Breisch, H. 1993. Harvest, storage and processing of chestnuts in France and Italy. Proc. International Congress on Chestnuts, 429-436.

Canbolat, Ö., E. Tamer, and E. Açıkgöz. 2007. Chemical composition, metabolizable energy and digestibility in pea seeds of differing testa and flower colors. J. Biol. Environ. Sci. 1 (2):59-65.

Cecchini, M., M. Contini, R. Massantini, D. Monarca, and R. Moscetti. 2011. Effects of controlled atmospheres and low temperature on storability of chestnuts manually and mechanically harvested. Postharvest Biol. Technol. 61:131-136.

Conedera, M., M. Jermini, A. Sassella, and T.N. Sieber. 2005. Raccolta, trattamento e conservazione delle castagne; caratteristiche del frutto e principali agenti infestanti. Sherwood 107:5-12.

Correia, P., A. Leitao, and M.I. Beirao-da-Costa. 2009. The effect of drying temperatures on morphological and chemical properties of dried chestnut flour. J. Food Eng. 90:325-332.

Cristofori, V., M. Muganu, P. Graziosi, G. Bertazza, and C. Bignami. 2009. Comparison of nut traits and quality evaluation of chestnuts (Castanea sativa Mill.) germplasm in Latium region (Central Italy). Acta Hort. 815:133-140.

De La Montana Miguelez, J., M. Miguez Bernandez, and J.M. Garcia Quejeiro. 2004. Composition of varieties of chestnuts from Galicia (Spain). Food Chem. 84:401-404.

Donis-Gonzalez, I.R., D.W. Fulbright, and E.T. Ryser. 2009a. Shell mold and kernel decay of fresh chestnuts in Michigan. Acta Hort. (ISHS) 866:353-362.

Donis-Gonzalez, I.R., D.W. Fulbright, E.T. Ryser, and D. Guyer. 2009b. Efficacy of postharvest treatments for reduction of molds and decay in fresh Michigan chestnuts. Acta Hort. (ISHS) 866:563-570.

Donis-Gonzalez, I.R., C. Medina-Mora, S. Stadt, M. Mandujano, and D.W. Fulbright. 2009c. The presence of mycotoxins after ninety days of storage in fresh chestnuts. Acta Hort. (ISHS) 844:69-74.

Ertan, E., G. Seferoğlu, G.G. Dalkılıç, F.E. Tekintaş, S. Seferoğlu, F. Babaeren, M. Önal, and Z. Dalkıliç. 2007. Selection of chestnuts (Castanea sativa Mill.) grown in Nazilli district Turkey. Turk. J. Agr. For. 31(2):115-123.

FAO. 2014. Food and Agriculture Organization of the United Nations statistical database, Rome.
Gaugler, M. and W.J. Grigsby. 2009. Thermal degradation of condensed tannins from radiata pine bark. J. Wood Chem. Technol. 29:305-321.

Ilori, M.O., S.A. Adebusoye, O.O. Amund, and B.O. Oyetoran. 2007. A study of tannic acid degradation by soil bacteria. Pak. J. Biol. Sci. 10(18):3224-3227.

Jaynes, R.A. 1979. Chestnuts, nut tree culture in North America. Northern Nut Grw. Assoc. Inc., Hamdem, CT. p. 111-127.

Jermini, M., M. Conedera, T.N. Sieber, A. Sassella, H. Schärer, G. Jelmini, and E. Höhn. 2006 Influence of fruit treatments on perishability during cold storage of sweet chestnuts. J. Sci. Food Agr. 86:877-885.

Jiang, N.H., Y. Zhong, and J.Y. Chen. 2004. Study on the effect of heat treatment on physiology and storage life of chestnut. J. Fruit Sci. 21 (3):237-240.

Karaçalı, I. 2004. Postharvest storage and marketing of horticultural crops. Ege University Agricultural Faculty publications, 494, İzmir.

Kınay, A. and I. Karaçali. 2001. Effects on the quality of packaging types and storage conditions for storing fresh chestnut fruit. J. Ege Univ. Agr. Fac. 38(1):25-32.

Koyuncu, M.A., E. Ertan, E. Savran, and T. Dilmaç Ünal. 2003. Effects on cold storage of different packaging type of chestnut (Castanea sativa Mill.). Proc. IV. National Horticulture Congress, 295-297. Antalya.

Li, Y., Y.L. Zhang, Z.G. Cheng, and H. Wang. 2006. Influence of treatments on postharves physiology and storage effect of chestnut. J. Agric. Univ. of Hebei 29(1):50-53.

Marinelli, C., M. Migliorini, L. Funghini, T. Turchetti, B. Zanoni, and S. Canuti. 2009 Marrone del Mugello PGI: The "water curing" process. Acta Hort. 844:47-52.

Mencarelli, F. 2004. Postharvest handling and storage of chestnuts-Compendium, FAO. InPHO. 15 Sept. 2010. <http://www.fao.org/inpho/>.

Miller, G. 2009. A simple chestnut peeling process and properties of the peeled kernels. Acta Hort. 844:33-40.

Morris, D.L. 1948. Qualitative determination of carbohydrates with Dreywood's antrone reagent. Science 107:254-255.

Nomura, K., Y. Ogasawara, H. Uemukai, and M. Yoshida. 1995. Change of sugar content in chestnut during low temperature storage. Acta Hort. 398:265-276.

Nour-Eldin, S., D. Gerasopoulos, and I. Metzidakis. 1995. Effects of storage conditions on chestnuts quality, post-harvest physiology, pathology and technologies for horticultural commodities: Recent Advances, Agadir Morocco, 196-201.

Pinto, P., S. Cabo Verde, M.J. Trigo, A. Santana, and M.L. Botelho. 2007. Food irradiation: Microbial, nutritional, and functional assessment. Radionuc. Concent. Food Environ. 16:411438.

Portela, E., J.V. Ferreira-Cardosa, and J. Louzada. 2009. Boron deficiency in chestnut-Effect of boron application on nut yield and quality. Acta Hort. 866:315-320.

Rouves, M. and J.P. Prunet. 2002. New technique for chestnut storage: Effects of controlled atmosphere. Intl. Inf. Syst. Agr. Sci. Technol. 186:33-35.
Seferoğlu, S. and E. Ertan. 2009. The determination of nutrient status of chestnut plantations in Nazilli-Aydın. Adnan Menderes Univ. J. Fac. Agr. 6(2):17-24.

Soylu, A. 2004. Chesnut growing and properties. Hasad, İstanbul.

Talasila, P.C., A.C. Cameron, and L. Taylor. 1995. Storage and modified-atmosphere packaging of Chinese chestnuts (Castanea mollissima). HortScience 30:815 (abstr.).

Tian, B., H. Tao, Z. Hai-ying, L. Hong-wei, and L. Li-ping. 2009. Changes in carbohydrate metabolism in coated chestnuts during storage. Acta Hort. 844:75-82.

Tzortzakis, N. and I. Metzidakis. 2012. Determination of heat stress and ultra low oxygen in chestnut storage under control and modified atmospheres. Food Nutr. Sci. 3:387-393.

Upchurch, B.L., H.A. Affeldt, D.J. Aneshansley, G.S. Birth, R.P. Cavalieri, P. Chen, W.M. Miller, Y. Sarig, Z. Schmilovitch, J.A. Throop, and E.W. Tollner. 1993. Detection of internal disorders, p. 80-85. In: Proc. of the Inter. Workshop United States-Israel Binational Agricultural Research and Development Fund, vol. 5, American Society of Agricultural Engineers, Sponkane, WA.

Uylaser, V., B.K. Incedayı, C. Mert, and A. Soylu. 2009. A research on suitability of some chestnut cultivars for candied chestnut. Acta Hort. 866:571-579 (ISHS).

Vasconcelos, M.C., R. Bennett, E. Rosa, and J.V. Ferreira-Cardosa. 2010. Composition of European chestnut (Castanea sativa Mill.) and association with health effects: Fresh and processed products. J. Sci. Food Agr. 90:1578-1589.

Vasconcelos, M.C., R. Bennett, E. Rosa, J.V. Ferreira-Cardosa, and F. Nunes. 2009. Industrial processing of chestnut fruits (Castanea sativa Mill.) - Effects on nutrients and phytochemicals. Acta Hort. (ISHS) 866:611-617.

Wang, X., C. Li, S. Tang, and W. Tang. 2000. Mechanisms of chestnut rotting during storage. HortScience 35:407 (abstr.).

Washington, W.S., A.D. Allen, and L.B. Dooley. 1997. Preliminary studies on Phomopsis castanea and other organisms associated with healthy and rotted chestnut fruit in storage. Australas. Plant Pathol. 26:37-43.

Wells, J.M. and J.A. Payne. 1980. Mycoflora and market quality of chestnuts treated with hot water to control the chestnut weevil. Plant Dis. 64:999-1001.

Xiang-wen, R. and R. Ping. 2009. Degradation of the tannin of Punica granatum peel by Aspergillus niger. J. Northwest For. Coll. 24(2):101104.

Xiaodong, W., M. Kangsen, Z. Yanjiao, A.Q. Hui, X. Wei, Z. Wenbing, and H. Haibin. 2013. Degradation of tannins and phytic acid in double-low rapeseed meal by Aspergillus niger in solid fermentation and optimization of fermenting condition. J. Ocean Univ. China 43 (2): $15-22$

Xiao-qing, Z., W. Hai-xia, Q. Ling, L. Su-hua, L. Zheng-ping, and W. Yan-min. 2009. Preliminary studies on pathogenic fungi of chestnut fruit rot and its control. Acta Hort. 844:83-88. 